\title{
THE POTENTIAL ROLE OF CUSTOMS IN THE MANAGEMENT OF MARINE SECURITY IN THE SOUTH CHINA SEA CONFLICT
}

\author{
Erti Fadhilah Putri ${ }^{1}$ \\ Kukuh Setyo Pambudi ${ }^{2}$
}

Peace and Conflict Resolution, Universitas Pertahanan ${ }^{1,2}$

Email:ertisafira@gmail.com ${ }^{1}$

Email: kukuhpambudi@ymail.com ${ }^{2}$

\section{ARTICLE INFORMATION}

Received date

[01-10-2020]

Revision

[05-12-2020]

Accepted date

[22-12-2020]

\begin{abstract}
This paper aims to provide an insight into the role that Customs can play concerning the possible conflicts in the South China Sea. The South China Sea (SCS) area is one of the places that has recently heated up with many countries fighting over claims. The conflict heats up when the two giant countries, namely China and the United States, take part in the conflict in this region and result in an increasingly heated tension. Indonesia, as one of the countries having interests in the South China Sea, where the Indonesian EEZ region is located, should be vigilant and prepare itself. Therefore, every component of Indonesia's national defence and security forces must be ready to avoid the worst possibility. One of the elements in maintaining sovereignty in the sea area is Customs. So that with the power and authority possessed by Directorate General of Customs and Excise (DGCE), it has the potential to become a reserve power and support Indonesia's maritime security. This paper is a presentation from a literature review process. This paper suggests the potential role of Customs concerning maritime security in the South China Sea region.
\end{abstract}

Keywords: Customs, Maritime Security, South China Sea, Conflict 


\section{INTRODUCTION}

Directorate General of Customs and Excise (DGCE) is one of the conventional institutions in Indonesia that have existed since pre-colonial times. Directorate General of Customs and Excise have become increasingly known since the arrival of Verenigde Oostindische Compagnie (VOC). The Directorate General of Customs and Excise was coordinating a flow of European trade to Indonesia. During the Dutch colonial era, the term Customs was known as douane, which referred to customs officers. At that time, douane had the function of managing fees for incoming and outgoing goods and also levying certain items following applicable laws. During the Japanese rule in Indonesia, customs duties changed and only responsible for excise levies. Since Indonesia became independent, the function and authority of customs returned to take care of customs and excise levies (beacukai.go.id, 2013).

The existence of Customs and Excise for a country is essential so that customs agencies become a global agency that almost all countries in the world have (DG Customs and Excise, 2013). In international forums, customs institutions are known as Customs Administration, whose tasks are limited to customs. In Indonesia itself, the official customs institution was formed as part of the Indonesian agency in 1945 under the name Customs and Excise Position. In 1948 the Customs and Excise Office changed its name to the Bera and Excise Bureau until 1965. Until now the name used for customs agencies is the Directorate General of Customs and Excise (DGCE) (Baideng, 2014).

The Directorate General of Customs and Excise has the main task of compiling the formulation and implementation of policies that include supervision of law enforcement, services and optimization of state revenues in the customs and excise sector. Specifically, Customs has to secure and collect state revenue from the import and export duties and excise sector, in addition to supporting the smooth flow of imported and exported goods and preventing and controlling prohibited and restricted goods that can harm people and state security. Then customs also has an additional function to guard the territorial of Indonesian border (beacukai.go.id, 2013).

In order to maintain maritime security, Directorate General of Customs and Excise also conduct marine patrols. Patrols conducted by Directorate General of Customs and Excise are a form of contribution in the context of anticipating and overcoming transnational crimes and maintaining maritime security. As for the legal basis for the 
DJBC marine patrols, namely Law No. 17 of 2006 concerning Amendments to Law No.10 of 1995 concerning Customs. Directorate General of Customs and Excise uses patrols in the context of preventing and finding any violations of fiscal security. Marine patrols can also be used for other justified purposes as long as coordination with institutions related to maritime security (Asep, 2017).

In its development, marine patrols have played a vital role. Based on the history of marine patrols, customs have played an essential role in achieving national interests. The tasks of DGCE are secure government policy related with the traffic of goods entering and leaving Customs Territory and Customs and Excise levies as well as other state levies based on the prevailing government regulations and laws. but also play an active role in the country's defence and security operations. This can be seen from the vital role of marine patrols as an aid fleet in the struggle for West Irian to the conflict in Timor Timor, even in the East Sumatra region, the Customs and Excise patrol boat was also used as a ferry crossing between Tanjung Balai Karimun to Tanjung Pinang (Asep, 2017).

The heating up of the geopolitical development of the Indo-Pacific region will undoubtedly have an impact on Indonesia's maritime security. The role of customs is very much needed not only in terms of Directorate General of Customs and Excise but also for other maritime security such as in assisting state defence and security operations. The escalation is already a development and militarization in the South China Sea region will impact Indonesia's security, not only in matters of sovereignty but also on law enforcement and national defence (Lo, 2020). Therefore, the presence of the Director General of Customs and Excise of Indonesia at sea is a potential force that can safeguard Indonesia's sovereignty. Customs as one of the law enforcers at sea will represent the presence of the state to remote and frontier regions. These insightful efforts through customs at sea are a form of integrated and compiled national defense with the aim of protecting the entire homeland and spilled Indonesian blood.

\section{LITERATURE REVIEW}

\subsection{SOUTH CHINA SEA CONFLICT}

The Maritime Border Dispute in the South China Sea Region is currently experiencing a high escalation; this is evidenced by the heating up of disputes between countries even under the realm of international law. According to Junef (2018) the South China Sea Conflict is a maritime teritorial conflict which is caused by dispute of borders 
by several countries. Territorial disputes in the South China Sea region, especially disputes over ownership of the Spratly Islands and Paracel Islands, have a long journey. History shows that the control of these islands has involved many countries, including the People's Republic of China (PRC), Vietnam, which then also involved Malaysia, Brunei, the Philippines and Taiwan. Territorial disputes and control of islands in the South China Sea, preceded by China's guidance on all islands in the South China Sea region, refer to historical records, the discovery of island clusters by fishers. From the perspective of the Chinese State, since 2000 years ago, the South China Sea has been a shipping route. Beijing asserts that the first to discover and occupy the Spratly Islands was China, supported by Chinese archaeological evidence from the Han dynasty (206-220 BC). In this case, Vietnam takes the opposite step, namely by considering the Spratly and Paracel Islands as part of its sovereign territory. Vietnam maintains that the Spratly and Paracel islands have been effectively occupied since the 17 th century when the two islands were not under the control of a country (Noor, 2015).

In historical perspective, Vietnam did not recognize Chinese sovereignty in the South China Sea Region; this can certainly be seen where when World War II ended, South Vietnam occupied the Paracel Islands and several island groups in the Spratly Islands. In history, it is also written that Vietnam has also occupied the Spratly Islands since the outbreak of World War II. Furthermore, the Philippine State also claimed the Spratly archipelago in the east and 1978 again occupied the Pratas island group (Wittner, 2020). This then became one of the bases that made matters in the South China Sea even more complicated, because at this time the Spratly Islands had changed hands of power and had been built as a military base by the PRC. Even so, efforts to defend the territory were still carried out and became one of the agendas brought by the Philippines to the International Assembly (Chris, 2016).

The Philippines' claim to the South China Sea area began in 1971, but the Filipinos only occupied the Spratly archipelago in 1978. The reason for the Philippines occupying the area was because this land was not currently owned by any other country. The position of the Philippines was also strengthened by the existence of the 1951 San Francisco agreement, which, among other things, stated that Japan had given up its rights to the Spratly Islands and that the islands had no master or in other words, Japan had released the islands without delegating with other countries. The Philippines claims most of the 
Spratly Islands, a region called Kalayaan in 1971 and strengthens its claim by enacting a Presidential Regulation in 1978, and PRC Rule Number 55 of 1992 which governs the area (Prayoga, 2015).

Malaysia is also an actor who participates in the claim to the South China Sea area. It can be seen that Malaysia officially announced the boundaries of the continental shelf, which includes the Spratly island group which borders the territory claimed by China. This action taken by Malaysia is one of the efforts to protect its territory and exploit the natural resources under it. Malaysia was also the last country to deploy its troops, in late 1977 and now occupies several islands from the Spratly archipelago (Wittner, 2020).Then the Brunei state also claims the waters in the southern China sea area, but what distinguishes it from claims from other countries is that Brunei does not determine the "land base" while other countries such as China, Vietnam, the Philippines and Malaysia have determined their "land base" in an island region in the south china sea. Brunei Darussalam only contested on the continental shelf with Malaysia in 1979 (Junef, 2016). The existence of Brunei's protests against Malaysia in the southern China sea area also resulted in the deterioration of relations between the two countries. However, Brunei firmly stated that it was for a peaceful conflict resolution so that until now the conflict between the two countries was relatively calm, not yet causing an open conflict towards a war between the two countries (Prayoga, 2015).

Apart from the overlapping claims between countries in the South China Sea area. The dispute between countries in this region also has a high escalation where there is a physical clash using military force. The first armed conflict in the South China Sea region was in 1979 between China and Vietnam, which had brought losses to Vietnam were several soldiers died in the battle / Show Force (Prayoga, 2015). Also, an open dispute occurred in 1988 where China and Vietnam were involved in a confrontation in the Spratly Islands, the two countries mobilized their military strength, this of course resulted in casualties on both sides, but the party with the highest number of victims was Vietnam, namely 70 Vietnamese military personnel were killed (Noor, 2015).

In 2009 China began to build up its military force in the South China Sea to strengthen the legitimacy of the nine-dash line's territorial claims. China submits territorial claims against the Nine dash line in the South China Sea to the United Nations. The militarization of Chinese power in the South China Sea began in 2009 with Beijing 
trying to legitimize and secure its disputed territorial claims in the South China Sea. Immediately after China submitted maps to the United Nations including on 7 May 2009. On the opposite side of the Philippines filed a diplomatic protest against China for claiming the entire South China Sea illegally. Vietnam and Malaysia filed a joint protest a day after China submitted its maps to the United Nations. Indonesia also registered its protest, although it has no claim to the South China Sea. The existence of protests brought to the country of China did not stop China from continuing its ambitions in the South China Sea (Backman, 2015).

From ASEAN members, only the Philippines took the case to the International Arbitration Court in 2013 and won in 2016. The Philippines' victory over China was welcomed by Vietnam and the United States, while China said it did not recognize the decision and continued to declare the South China Sea as their waters based on existing history. The dispute over the South China Sea will continue (Junef, 2016). China's actions in the South China Sea have become increasingly aggressive after the International Arbitration Board's decision was issued. China began to carry out various patrols in the South China Sea area on coast guard ships, then the United States began to enter into disputes and reject any intimidation by China of ASEAN countries and reject claims that were not based on international Law against the waters of the South China Sea. The two countries showed their rivalry in the South China Sea by deploying military forces.

The increase in military tension in the region and the aggressive actions of the United States and China have raised concerns over the development of escalation in Indonesia. Indonesia has begun to seek Balance of Threat measures (Syailendra, 2017) and annul actual threats that could threaten national security. Indonesia is starting to show its strength and assertiveness in Southeast Asia. The Indonesian Navy carries out military exercises in the Natuna Islands near the waters of the Nine-dash line. The development of military issues in this region certainly makes Indonesia more adaptable to the possibility of military confrontation. So that in the problems faced now, how does Indonesia see the challenges ahead with a balance of threat approach in regional geopolitics.

\subsection{INDONESIAN SEA DEFENCE AND SECURITY}

Geographically, Indonesia is an archipelago with two-thirds of the ocean area larger than land. This can be seen from the coastline on almost every island in Indonesia 
along approximately 81,000 kilometres. Indonesia's strategic position, which is the meeting point for the world's communication lines between the Pacific Ocean and the Indian Ocean as well as the Asian continent and the Australian continent. Indonesia also has maritime borders with ten countries, namely India, Australia, Vietnam, the Philippines, Singapore, Malaysia, Thailand, Papua New Guinea, and Timor Leste. Indonesia's geographic constellation as the largest archipelagic country with a vast sea area, a strategic location for a world transportation hub, has implications for geopolitical and geostrategic challenges in order to maintain the defence and security of Indonesia's territory (Gischa, 2019).

National defence is essential in supporting the survival of the nation and the State. Strong defence will increase the ability to face threats, both actual and potential threats. In the Republic of Indonesia Law Number 3 of 2002 concerning State Defence, it is stated in Article 3 paragraph 2 that "National defence is prepared by taking into account the geographical conditions of Indonesia as an archipelagic country". This, of course, shows that the orientation of the country must refer to the geographical conditions of Indonesia as an archipelagic country (A \& Pramono, 2018).

Archipelago Orientation implies that the defence of an archipelago nation sees more threats coming from outside. This is following the thread formulation in Article 7 of Law No.3 of 2002, which no longer mentions threats from within the country and threats from abroad, but instead states more clearly in terms of military threats and non-military threats. According to the Director of Strategic Analysis (Diranstra) of the Directorate General of Defence Strategy of the Indonesian Ministry of Defence Marsma TNI Adityawarman, S.E., M.M., who stated that the development of a maritime defence posture is needed to deal with all maritime threats. "Maritime defence posture is needed to deal with all threats, including safeguarding sovereignty and natural resources, maintaining shipping safety and maritime security in national jurisdictions; and maintaining a peaceful situation in the Indian and Pacific oceans" (Lemhanas, 2019).

In realizing maritime security, efforts to enforce sovereignty and Law are needed. As an archipelagic country, law enforcement at sea is essential; this refers to the negative impact of lawlessness at sea for a country, as for activities that violate the Law that is mostly carried out at sea, such as illegal fishing, illegal migrants, illegal logging, and illegal mining. Decisive action is needed to prevent violations (Setiadji, 2017). 
Currently, Indonesia is faced with an actual geopolitical and geostrategic threat in the South China Sea, where the rivalry between the United States and China is increasingly heating up in deploying military forces in the waters. This has become a reference for Indonesia to fix maritime security governance, which currently still needs much improvement. Currently, Indonesia is faced with overlapping or intersections of authority between ministries or government agencies which cannot be avoided. To date, there are more than fifteen statutory-level legal arrangements that have regulations on activities or issues in the marine area. Of all the agencies that have law enforcement duties derived from this Law, six agencies have patrol boats at sea. The law enforcement agencies that have a sea patrol task force are Navy troops, Police - Directorate of Water Police, Ministry of Transportation - Directorate General of Marine Transportation, Ministry of Marine Affairs and Fisheries - Directorate General of Marine Resources and Fisheries Supervision, Indonesia Coast Guard and Directorate General of Customs and Excise (Baideng, 2014).

The Indonesian Navy has a particular role in maritime security. Its main task is to protect the sovereignty of the sea area from all threats that arise from outside the territory of Indonesia. Meanwhile, with so many law enforcement agencies on duty at sea, security and safety for all activities in the territorial sovereignty and jurisdiction of Indonesian waters should be more secure. However, recent complaints have been increasingly voiced by relevant stakeholders that the current situation has made the economic costs of activities at sea even higher. This was conveyed directly by the chairman of the Indonesian Shipowners Association (INSA) to President Jokowi (Arief, 2020). Also, there have been many studies and publications that noted how weak law enforcement at sea is because coordination between law enforcers is considered less than optimal (Setiadji, 2017).

Efforts have been made to improve the coordination pattern of law enforcement at sea since 1972. However, internally there are several barriers that affect law enforcement at sea, one of which is the regulations owned by each agency or agency that deals with maritime affairs. Heriyanto Marwoto, Expert Staff of the Ministry of Maritime Affairs and Fisheries (KKP) stated that there are a lot of laws in general that have to be synchronized and that is very urgent (Yeremi, 2014). In a public discussion on "Political Will in the field of Law Enforcement at Sea", Herutanto stated that the existence of laws 
that have not been synchronized between institutions has resulted in a conflict of authority between agencies/institutions (Yeremi, 2014).

The policy direction for marine development is still running independently. This is as previously stated, that there is no mechanism or institutional arrangement that is able to synergize and integrate marine development policies. As a result, handling in marine development is sometimes ineffective and can even lead to conflicts between institutions. for example, in the Riau sea sand case, which caused problems between state institutions, namely between the Ministry of Energy and Mineral Resources, the Ministry of Industry and Trade and the Ministry of Maritime Affairs and Fisheries. From this case it is clear that marine development does require a coordination mechanism and institutional arrangements that are able to integrate all the interests of the state institutions involved (Kusumastanto, 2010).

\section{ANALYSIS AND DISCUSSION}

\subsection{THE POTENTIAL ROLE OF CUSTOMS IN THE SOUTH CHINA SEA}

As stated in the Regulation of the Minister of Finance of the Republic of Indonesia Number 184/PMK.01/2010 concerning the Organization for the Work Procedure of the Ministry of Finance dated 11 October 2010, DGCE's main tasks are: to carry out some of the main tasks of the Ministry of Finance in the field of Customs and Excise, based on the policies set by the Minister and securing government policies relating to the traffic of goods into or out of the Customs Area and Collection of Import Duty and Excise and other state levies based on applicable laws and regulations (Albram, 2017).

Customs and Excise Officers have the authority to prevent imported or exported goods, according to Law No.10 of 1995 as amended by Law No. 17 of 2006 concerning Customs. Article 77, paragraph 1 in the Law gives authority to Customs and Excise officials to carry out customs administration duties. Administrative measures taken can be in the form of delaying the release, loading and transportation of imported or exported goods until customs obligations are fulfilled, and efforts to prevent the departure of a vehicle means in the form of aircraft, ships, trucks and etc (Asep, 2017).

In carrying out supervisory duties, the Customs and Excise position is in the forefront of Republic of Indonesia (NKRI) in its capacity as supervision of the flow of goods and people at the entrance to the country, namely through Airport and seaport (Seaport) and border doors. According to Albram (2016) Land routes (Border) include as 
an important border to other countries. The supervisory task is a task that supports the main task of collecting import and exit duties as well as Excise. Other than that, Customs and Excise have the authority to perform general duty in ascertaining whether the number and types of goods imported or exported are under the notification, including brands and types of goods, the provisions of the prohibition of restrictions are fulfilled or not (Asep, 2017). In conducting surveillance, Customs uses patrol boats to monitor the smugglers of prohibited goods and harms national security (Albram, 2017).

Customs also plays an active role in carrying out synergy and coordination of marine patrols with various institutions or agencies in enforcing laws at sea and in coordinating the interests of rescue and other government activities, such as joint operations for narcotics suppression with Indonesia National Council of Anti-Drugs (BNN) and Indonesian Police, Indonesian Search and Rescue Operations, national parade (Parade Nusantara), and coordination with the Indonesian Navy, Nusantara and Bhuana Nusantara by Bakamla. Ministry of Marine Affairs and Fisheries (KKP), KPLP, Directorate General of Transportation, Polair, and other Ministries related to the implementation of marine patrols, information exchange and case handling processes (Asep, 2017).

DJBC as one of the institutions that carry out the mandate in the context of enforcing Customs and Excise laws, DBC is equipped with Customs and Excise patrol boats and their equipment (Warta Bea Cukai, 2017). DJBC itself has six types of patrol boats and 5 Operational Facility Bases (PSOs). Some of these patrol boats are now distributed in five Operational Facility Base (PSO) areas, including Batam, Tanjung Balai Karimun, Tanjung Priok, Pantoloan, and Sorong (Asep, 2017).

Customs and Excise Marine Patrols is one of the most active marine patrols to monitor the entry and exit of illegal goods around the Indonesian waters. Of course, this cannot be separated from the coordination between institutions in order to maintain maritime security. Customs Marine Patrols have shown significant progress in coordination between agencies in matters of maritime security from threats that endanger Indonesia's national security (Warta Bea Cukai, 2017).

In the history of Marine Patrols carried out by Customs, it has not only focused on maritime security but also national defence in the face of threats both military and nonmilitary threats. The Customs Marine Patrol was once an aid fleet in the struggle for West 
Irian to the conflict in Timor-Timor, even in the East Sumatra region, the Customs and Excise patrol boat was also used as a ferry crossing between Tanjung Balai Karimun to Tanjung Pinang. During the evacuation of boat people from Galang Island in 1996. At that time, DJBC participated with other agencies, such as the TNI, Polri, Immigration, and so on to bring boat people from Vietnam who fled to Galang Island to be returned to their home country in Vietnam. At that time, the customs patrol boat was alerted as a carrier reserve because previously, the Vietnamese Government had refused to have its refugees carried by the Indonesian Navy ship (Warta Bea Cukai, 2017).

The heating up of the geopolitical development of the Indo-Pacific region will undoubtedly have an impact on Indonesia's maritime security. The escalation of conflict in the South China Sea has indicated a military confrontation in these waters. The two countries, the United States and China, have deployed military forces in military bases around the South China Sea area (Lo, 2020). Furthermore, the dynamics of maritime disputes in East Asia have become the main driver of competition for naval arms among regional countries. This regional trend cannot of course be separated from the observations of Indonesian defense planners. The main concern of Indonesia is that if the actions of regional countries in carrying out modernization are not in accordance with existing security needs, it will have an impact on the arms race. The dynamics of the arms race in the region will weaken national security and increase the likelihood of armed conflict at sea (CSIS, 2016).

In recent years, China has built bases, artificial bases and accused them of being specially made for military purposes. This development is a major problem for Southeast Asian countries. China is increasing its military capabilities in line with economic growth and the presence of the United States in the South China Sea, not only improving the quality but also the quality of its weapons (Harris, 2017). China has built a strong navy, complete with a submarine force and an increasing number of maritime law enforcement vessels. within the Asia Pacific region China ranks first in the number of maritime law enforcement vessels (Kuik, 2016).

In responding to a regional environment that can threaten national security, especially maritime and maritime security, Malaysia is rapidly improving the capabilities of its maritime security institutions. Malaysia begins modernizing the New Generation Patrol Craft (NGPC) Patrol boat. In this case Malaysia and Indonesia have similarities 
where there is a problem of overlapping authority between law enforcement agencies. Even after twelve years of its establishment, the MMEA (Malaysian Maritime Enforcement Agency) is still struggling to become an effective maritime law enforcement agency. The most complex problem facing the MMEA is the unresolved issue regarding the proper demarcation of law enforcement forces between the MMEA and other enforcement agencies such as maritime police, customs, immigration, and environmental and fisheries departments. In 2017, Malaysia rebranded to the 'Malaysia Coast Guard' for international identification and became an agency with a multi-agency system for law enforcement at sea. one of its functions is Jurisdiction to prevent or punish infringement of customs, fiscal, immigration or sanitary laws (Abdul, 2016).

This is what Indonesia needs to do as Malaysia has done in responding to the dynamics occurring in the South China Sea. As a maritime country, Indonesia does not yet have a solid marine law enforcement agency, such as relations in China, Malaysia and the United States which already have one one-stop agency, namely the Coast Guard or the Maritime Coast . Other alternatives achieved by the Government to date are in optimization of marine security institutions. With the current conditions of the arms race, which is currently a real threat in the South China Sea region, not only China and the United States but also regional countries. Indonesia must be able to improve its maritime security and defense capabilities with the potential for greater conflicts with maritime weapons. Customs as a law enforcement agency that owns patrol boats can be a supporting component if critical conditions occur.

\subsection{CUSTOMS AND EXCISE COOPERATION IN THE SOUTH EAST ASIA}

Maritime security is critical to the stability and prosperity of the Southeast Asia (SEA) region, and the broader domain of the ASEAN Regional Forum. Issues related to maritime security represent some of the most pressing but potentially useful areas for ARF cooperation; The region's seas are becoming congested and contested, countries continue to invest in sophisticated civilian naval and maritime capabilities, and terrorists and other criminals take advantage of the relatively porous boundaries of the sea as a vehicle to develop their criminal agendas. Due to the importance of shipping and crosssea trade in the ARF region, several forms of cooperation have been developed, both bilaterally and through multilateral forums, with the aim of fighting and preventing threats related to maritime security (ASEAN Regional Forum, 2019). 
ASEAN customs is one of the keys in the ASEAN economic pillar, ASEAN is currently focusing on running the ASEAN economic community effectively by utilizing the role of customs agencies in law enforcement at sea. Currently, synergy and coordination between sectors in ASEAN is very important, because almost all problems pertain to customs and excise of other countries. This meeting is the highest forum in customs in ASEAN that discusses various strategic interests of excise in order to support the ASEAN Economic Community. As additional information, the 2017 ASEAN DG Meeting was held simultaneously with the 50th anniversary of ASEAN. Thus, the spirit and solidarity of ASEAN are expected to be valuable assets to achieve ASEAN goals. Present at the meeting were Customs leaders from 10 ASEAN member countries and the ASEAN Secretariat ( Ministry of Finance Indonesia. 2017)

The 15th ARF Ministerial Meeting established the first maritime forum, namely the ARF Inter-Sessional Meeting on Maritime Security (ISM-MS) in Singapore in July 2008. Ministers at the 18th ARF in Bali, Indonesia adopted the ARF Work Plan on Maritime Security was first launched in July 2011 to build general perceptions about threats and challenges in maritime security. Over the next three years, the work plan guides cooperative activities to support ISM-MS ARF. Ministers at the 22nd ARF Meeting in Kuala Lumpur, Malaysia in August 2015 adopted the second ARF Work Plan on Maritime Security 2015-2017. However, the dynamic nature of the regional security landscape, coupled with the recognizable progress made in building trust, exchanges of best practices and practical cooperation under ARF ISM-MS and other forums, underscores the need for ARF to keep the Work Plan under review. At the 9th ARF InterSessional Meeting on Maritime Security in Tokyo, Japan on 8-9 February 2017, ARF members praised the role of the Second Work Plan as a guiding document for maritime security activities and discussions under the ARF framework. ARF members emphasized the need to ensure that in developing the ARF Work Plan on Maritime Security for the 2018-2020 period, (ASEAN Regional Forum, 2019). The initiatives undertaken by the ARF are closely aligned with other maritime security mechanisms in the region such as ADMM-Plus and EAS. to avoid duplication of effort. The Tokyo meeting further noted the importance of information sharing and the need to identify gaps in maritime treaties and frameworks in order to develop a new robust and effective Work Plan (ASEAN Regional Forum, 2019). 
Customs and Excise also collaborate with neighbouring countries for joint marine surveillance patrols; this cooperation has been embodied in the bilateral cooperation between DGCE and Customs of the Kingdom of Malaysia (KDRM) since 1994, namely the implementation of the Coordinated Patrol of Indonesian and Malaysian Kastam (PATKOR KASTIMA). In addition to the implementation of patrols, data and information exchanges were also carried out related to the implementation of marine patrols carried out by the two customs institutions. On September 6 2017, the 15th bilateral meeting was held between Indonesia and Malaysia, one of the agendas at the meeting was sharing information about the customs information exchange system as a follow-up to the previous annual routine meeting. Currently, Customs is also reviewing marine surveillance cooperation with Singapore. As a follow-up, currently, a Draft Memorandum of Understanding (MoU) is being discussed between Customs and the Police Coast Guard (PCG) of Singapore regarding customs enforcement and coordinated patrols (Indo-Pacific Defence Forum, 2020).

\subsection{THE ROLE OF DGCE ON PROTECTING BORDERS}

Customs, as one of the tools of the State, has played a significantly central role in border borders, especially in the economic and fiscal fields. In general, the role of customs is known as monitoring and law enforcement in transnational economic offenses. Customs is also one of the country's backbones by providing control of the flow of goods in and out of goods, thereby avoiding leakage of state money (beacukai.go.id, 2019). Apart from being a supervisor for the entry and exit of goods in a country, Customs also has diversity in several country functions, as is the case in the United States, which combines its Customs and Excise officers into the immigration unit (Garret, 2018). The merger's function is to provide flexibility and an integrated function in controlling the flow of goods and borders at once.

Another role of customs abroad, which is quite different from that in Indonesia, is seen in Customs and Excise offices in China, which have a historical position with the ministry. According to Shujie and Shilu (2009), the modernization of China's customs service has a significant impact because Customs in China now has a decisive role in issuing policies and being the supervisor of the flow at the border. Likewise, with customs agencies in Europe, Customs is one of the core supervisors in border control. The existence of customs in Europe is central because it is integrated with the immigration 
service and becomes the implementer in supporting human presence in both goods and entering and exit Europe (Guild, 2017). Looking at several features of the customs services in these countries, it makes sense that the customs perspective can play a role in the border and take part in the conflict in the South China Sea. Customs can provide a role to guard borders and cooperate with immigration services or even the coast guard. The author sees the potential that exists in the customs office to be underutilized, especially in the context of the conflict that occurred in SCS.

Just as customs services abroad take part in border guarding and routine marine patrols, Indonesian Customs and Excise, with their powers, can be given a more prominent role. This argument also departs from the capabilities possessed by Customs and Excise officers who have been undergoing semi-military training (Adhitama and Aulia, 2017). Thus, the customs and excise officers must have the ready-to-time skills to serve a heavier role in maintaining the defense of the Indonesian State. The conditions of equipment and tools limited to Indonesia at sea can also be supported by the Indonesian Customs Service. This is based on Customs and Excise's ownership of 182 patrol boats, which of course, will have great potential in helping the process of patrolling Indonesia's defense sea (beacukai.go.id, 2018). This number will be amicable and can be integrated with the alutsista already owned by the TNI so that the role of Customs in border borders will be needed.

\subsection{PATROL BOATS AS SUPPORTING COMPONENTS IN MARINE DEFENSE}

In Law Number 17 of 2006, Law Number 10 of 1995 concerning Customs in Article 75 states that patrol boats are the authority of the customs and excise authorities in the supervision of transporters at sea or in rivers. In the next article it is also stated that the patrol or other means used by the customs and excise officers can be equipped with weapons but are still under government control. Patrol conducted for the sea area, its territory including inside and outside the port parts of the sea and all territorial waters of Indonesia the territorial sea, the auxiliary zone, the EEZ and the shelf continental. The authority that can be taken by customs and excise officials on patrol includes: taking action against. foreign ships or Indonesian ships violating the provisions of Indonesian waters; prevent actions that are contrary and harmful to sovereignty, security and state interests; combat smuggling in all forms; eradicating illegal immigrants; eradicating the 
trade in illicit goods such as narcotics, counterfeit money, gunpowder and firearms; eradicating robbery fish and other marine products; and international navigation (DGCE, 2018).

In times of peace, DGCE performs its function as a customs and excise agency that oversees the means of action in rivers and at sea as well as law enforcers in the event of a violation of the smuggling of goods and people and the eradication of drugs and objects that are prohibited by law. in the crisis scheme how the role of DGCE as a means of national defense. The current strength of the patrol boat fleet owned by Customs and Excise is 193 vessels consisting of several types, namely FPB with a size of 60 meters with steel and aluminum construction materials of two ships, FPB of 38 meters of aluminum construction materials as many as seven ships, FPB with a size of 28 meters of material. Aluminum construction of fourteen ships, FPB of 28 meters of laminated wood construction material of twenty ships, Verry Slender Vessel (VSV) of 15 meters of nine ships of kevlar and fiberglass construction materials, speed boats of 15 meters, 10 meters, and less than 10 meters with fiberglass construction material as many as 140 ships (Asep, 2017) . This number is certainly not proportional to the vast area of Indonesian waters. DGCE needs to modernize patrol boats, this is of course an effort to respond to the rampant violations of export and import goods as well as law enforcement at sea.

In addition to carrying out its functions efficiently, DGCE has been used on several occasions as an assistant in the defense sector. This certainly shows that previously between DGCE and the Naval Army. History records that the synergy between Customs and Excise and TNI has been established for a long time, at least since Customs was still an institution of the Dutch East Indies until then on October 1, 1946 it was designated as an institution of Customs and Excise Officers. Some historical records of cooperation between Customs and Excise and TNI, among others, are that Customs is the first agency to have a marine patrol boat other than the Navy in 1953 with a total of 3 patrol boats. Not only that, the participation of patrol boats in support of ABRI military operations such as in the landing of ABRI troops in Pekanbaru in order to crush PRRI / Permesta, Operation Tumpas Eradication of DI / TII Kahar Muzakar in South Sulawesi, intelligence operations and other tasks during the Dwikora / confrontation with Malaysia, and Operation Seroja East Timor (Media Indonesia, 2020). 
With the collaborative experience of the Indonesian Navy and the customs agency, if a crisis occurs, in this case it refers to a maritime armed conflict, the customs patrol boat will be used as a supporting component in the marine defense strategy during war. This is in line with what India has done with the single multi-task agency, namely the Indian Coast Guard. The Indian Coast Guard has acquired a wide range of capabilities both surface and airborne to undertake the assigned tasks during peacetime and to supplement the efforts of Indian Navy during the war (Ministry of Defence Government of India, 2016).

The concept of marine patrol by Customs has been packaged in marine customs or Customs marine patrols. Patrols conducted by Customs are patrols in securing borders from smuggling or illegal trade in cross-border routes. At the level of its duties, the Customs and Excise Patrol has had a significant impact on law enforcement at sea (Andiwi, 2018). So far, marine customs' role can be considered to be still at the level of working together and not yet becoming an integrated unit with other units or agencies in Indonesia. Customs marine patrols are usually carried out in several types of patrols in their duties and functions.

1. Independent patrol, namely marine patrol activities carried out following the working area of the DJBC Service Office or joint marine patrols in one regional office working area, which is carried out independently. This patrol uses patrol boats and crews of patrol boats owned or from the Operational Facility Base under them.

2. Integrated Patrol is a patrol activity carried out across work areas of the DJBC Regional Office by utilizing patrol boats and patrol boat crews owned by one or more Regional Offices. Some examples of integrated patrols include:

- Sriwijaya Net Operations

- Wallacea Net Operations

3. Special Patrols, namely patrol activities carried out jointly between DJBC and other Government Agencies or TNI / POLRI. The following are some examples of special patrols conducted by Customs:

- Operations with the BNN

- Operations with Bakamla

- Operations with the Indonesian Navy. 
4. Coordinated Patrol, patrol activities carried out in a coordinated manner between DJBC and other State Customs Agencies. As an example:

- Operation PATKOR KASTIMA

- operation OPTIMA PATKOR.

Although there have been several patrols, both independently and in incoordination, there is still a role that Customs and the Government can maximize if they want to have a maximum impact. Some things that can be done are integrating Customs and Excise with several other agencies such as immigration and having a joint coordination office specifically for border areas. There will be one data that can be shared both in the duties of each government agency and in efforts to guard the border. Furthermore, efforts to form a pattern of integration will also significantly impact Indonesia's efforts to maintain its position in disputed areas in the South China Sea.

\section{CONCLUSION}

The heating up of the geopolitical development of the Indo-Pacific region will undoubtedly have an impact on Indonesia's maritime security. The escalation of conflict in the South China Sea has indicated a military confrontation in these waters. The two countries, the United States and China, have deployed military forces in military bases around the South China Sea area (Lo, 2020).Furthermore, the dynamics of maritime disputes in East Asia have become the main driver of competition for naval arms among regional countries. This regional trend cannot of course be separated from the observations of Indonesian defense planners. The main concern of Indonesia is that if the actions of regional countries in carrying out modernization are not in accordance with existing security needs, it will have an impact on the arms race. The dynamics of the arms race in the region will weaken national security and increase the likelihood of armed conflict at sea.

Currently, Indonesia is faced with an actual geopolitical and geostrategic threat in the South China Sea, where the rivalry between the United States and China is increasingly heating up in deploying military forces in the waters. This has become a reference for Indonesia to fix maritime security governance, which currently still needs much improvement. Currently, Indonesia is faced with overlapping or intersections of authority between ministries or government agencies which cannot be avoided. Nowadays, there are more than fifteen statutory-level legal arrangements that have 
regulations on activities or issues in the marine area. Of all the agencies that have law enforcement duties derived from this Law, six agencies have patrol boats at sea. The law enforcement agencies that have a sea patrol task force are Navy troops, Police Directorate of Water Police, Ministry of Transportation - Directorate General of Marine Transportation, Ministry of Marine Affairs and Fisheries - Directorate General of Marine Resources and Fisheries Supervision, Indonesia Coast Guard and Directorate General of Customs and Excise.

One of the roles that can assist in Indonesia's defense at the border by Customs and Excise is establishing an integrated patrol and integrated control center. Many of the patrols being run are independent, while the joint patrols are only carried out in their respective capacities. Cooperation and integration are necessary in order to build better border forces. Therefore, making Customs and Excise one of the spearheads in border defense is an effort that can be done by the Indonesian government.

One of the agencies that can become a reserve resource when armed war occurs at sea is the customs and excise agency or DJBC. with a strength of 182 ships, DJBC can maintain the flow of goods and other fiscal affairs. future prospects of geopolitical challenges, obliging DGCE to develop a patrol function as a reserve component during war or use the merger of maritime security institutions into a multi-task Sigle Agency as carried out by the countries of China, Malaysia and the United States.

\section{REFERENCES}

A, I. N., \& Pramono, S. H. (2018). Konsepsi Pembangunan Kekuatan Dan Kemampuan Sistem Informasi Operasi Tni Al Dalam Mendukung Penyelenggaraan Strategi Pertahanan Laut Nusantara. Astro Journal, 104.

Adhitama, S., \& Aulia, D. R. R. (2017). Analisis Penerapan Sistem Pengendalian Manajemen Dengan Model Four Levers of Control Di Pusat Pendidikan Dan Pelatihan Bea Dan Cukai. Info Artha, 1(1), 35-46.

Agus Setiadji, S. (2017, may 18). Kekuatan Pertahanan Indonesia dalam Bingkai Negara Maritim. Indonesia.

Albram, D. (2017). Implementasi Tata Kelola Kewenangan Bea Dan Cukai Di Bidang Hak Kekayaan Intelektual (Hki) Di Indonesia. JIKH, 83-84.

Andiwi, C. F. (2019). Penyelesaian Perkara Illegal Logging Antar Pulau Hasil Tangkapan Patroli Bea Cukai di Wilayah Perairan (Studi Kasus Di Wilayah Kerja Pso Pantoloan) (Doctoral dissertation, Universitas Tadulako).

Arie Afriansyah. (2020 Juli). "Tata Kelola Keamanan Laut Indonesia." Sindonews.

Abdul Ghafur Hamid; Khin Maung Sein;Maizatun Mustafa ;Su Wai Mon. (2016). Entrusting Coast Guards with Maritime Law Enforcement Powers: Lessons For Malaysia (1). IIUM PJ 83 - 106. 
Asean Regional Forum. (2019, January). ASEAN Regional Forum Maritime Security Maritime Security. Retrieved September 2020, 2020, from ASEAN Regional Forum: http://aseanregionalforum.asean.org/wp-content/uploads/2019/01/ARF-MaritimeSecurity-Work-Plan-2018-2020.pdf.

Bea Cukai (2018). Marine Customs. (Online) https://www.beacukai.go.id/arsip/stt/marine-customs.html

Backman, R. C. (2015). ASEAN and South China sea dispute. In Entering Uncharted Waters? Asean and South China (pp. 15-20). Singapore: Institute of Southeast Asia Studies.

Baideng, R. A. (2014). Fungsi Dirjen Bea Cukai Dalam Lex et Societatis, 115.

CSIS. (2016). Diplomasi Pertahanan Maritim: Strategi, Tantangan, dan Prospek,Badan Pengkajian dan Pengembangan Kebijakan Kementerian Luar Negeri Republik Indonesia.

Diatta, C. S., Sow, A. A., \& Diouf, M. (2020). Customs and Traditional Management Practices of Coastal Marine Natural Resources in Lower Casamance: Perspectives of Valorisation of Endogenous Knowledge. Journal of Ecology and The Natural Environment, 12(2), 46-64.

Dirjen Bea dan Cukai. (2013, February 05). Sejarah Bea dan Cukai. Retrieved September 28, 2020, from Kementerian Keuangan Direktorat Jenderal Bea dan Cukai: https://www.beacukai.go.id/arsip/abt/sejarah-bea-dan-cukai.html.

Guild, E. (2017). Controlling frontiers: free movement into and within Europe. Routledge.

Gischa, S. (2019, december 10). Indonesia Sebagai Negara Maritim. Jakarta, Indonesia.

Garrett, T. M. (2018). An analysis of US Custom and Border Protection's tripartite Mexico border security policy. Annales. Etyka w życiu gospodarczym, 21(4), 89-111.

Indo-Pasific Defence Forum. (2020, June 15). The chief of Indonesia's new agency shares his ideas for countering piracy, illegal fishing and other threats to stability. Retrieved september 30, 2020, from Maritime Security: https://ipdefenceforum.com/2020/06/maritime-security/

Huzairi, H., Buhari, B., Lumaksono, H., Tukan, M., \& Alim, S. (2018). Pemilihan Model Keamanan Laut Indonesia Dengan Fuzzy Ahp Dan Fuzzy Topsis. Network Engineering Research Operation, 4(1).

Junef, M. (2018). Sengketa Wilayah Maritim Di Laut Tiongkok Selatan (Maritime Territorial Dispute in South China Sea). Jurnal Penelitian Hukum, 227.

Lemhanas. (2019, mei 14). Pembangunan Kekuatan Pertahanan dalam Konteks Poros Maritim Dunia. Retrieved September 30, 2020, from Lemhanas RI. http://www.lemhannas.go.id/index.php/berita/berita-utama/624-pembangunankekuatan-pertahanan-dalam-konteks-poros-maritim-dunia

Kadarisman, M. (2017). Kebijakan keselamatan dan keamanan maritim dalam menunjang sistem transportasi laut. Jurnal Manajemen Transportasi \& Logistik, 4(2), 177-192.

Lo, K. (2020, January 22). South China Morning Post. Retrieved September 15, 2020, from cmp.com/news/china/diplomacy/article/3044374/how-indonesias-south-chinasea-dispute-beijing-could-lead

Laut, t. B. K., \& Amalia. Analisis Kewenangan Badan Keamanan Laut Berdasarkan Peraturan Presiden Nomor 178 Tahun 2014.

Hariss B,Harris, JR (2017),"Menguasai Pertempuran Multi-Ranah", Indo-pasific Defense Forum Vol 42,No.4, 
Media Indonesia. (2020).Sinergi Bea Cukai dan TNI AL, Perkuat Penegakan Hukum di Laut Sumber: https://mediaindonesia.com/ekonomi/326838/sinergi-bea-cukai-dantni-al-perkuat-penegakan-hukum-di-laut

Munaf, D. R. (2013). Studi Analisis Tipikal Infrastruktur Keamanan Laut Di Pusat Dan Daerah. Jurnal Sosioteknologi, 12(28), 320-339.

Ministry of Defence Government of India (2016). Annual Report 2015-16

Kementerian Keuangan RI. (2017). Indonesia Appointed to Lead Asean Customs Leadership Meeting. Kementerian Keuangan RI

Noor, S. (2015). Sengketa Laut Cina \& Kepulauan Kuril. Makassar: Pustaka Pena Press Makassar.

Prayoga, T. N. (2015). Asean dan Isu laut Cina Selatan: Transformasi konflik menuju Tata Kelola Keamanan regional Asia Timur. Jurnal Penelitian Politik,Volume 12 No. 1 Juni 2015, 107.

Stefanus, D., \& Adiyanto, E. (2015). Komando Pengendalian Keamanan dan Keselamatan Laut. Gramedia Pustaka Utama.

Shujie, Z., \& Shilu, Z. (2009). The Implication of Customs Modernization on Export Competitiveness in China. Impact of Trade Facilitation on Export Competitiveness: A Regional Perspective, 66, 121-131.

Syailendra, E. A. (2017). A Nonbalancing Act: Explaining Indonesia's Failure to Balance Against the Chinese Threat. Asian Security, 237-238.

Tridoyo Kusumastanto. (2010). Kebijakan Tatakelola Kelautan Indonesia (Indonesia Ocean Governance Policy). Pusat Kajian Sumberdaya Pesisir dan Lautan, 2010. http://pkspl.ipb.ac.id/download/file/Tatakelola_Kelautan.pdf.

Undang-Undang Republik Indonesia Nomor 17 Tahun 2006 Tentang Perubahan Atas Undang-Undang Nomor 10 Tahun 1995 Tentang Kepabeanan.

KUIK Cheng-Chwee. (April 2016). China's "Militarisation” in the South China S_Three Target Audiences, East Asian Policy.

Asep, Ridwan. (2017). Patroli Laut DJBC Memiliki Peran Penting Sebagai Penjaga Pintu Gerbang Bangsa. Warta Bea Cukai, 14-18.

Wittner, L. (2020, August 10). Citizen for Global Solutions. Retrieved september 15, 2020, from https://globalsolutions.org/china-and-the-united-states-could-avoid-anunnecessary-war/

Whomersley, Chris. (2016). The South China Sea: The Award of the Tribunal in the Case Brought by Philippines against China-A Critique. Chinese Journal of International Law. 15. jmw011. 10.1093/chinesejil/jmw011.

Wulansari, E. M. (2014). Penegakan Hukum Di Laut Dengan Sistem Single Agency Multi Tasks. Media Pembinaan Hukum Nasional, 1-6.

Yeremia Sukoyo. (2014). Peraturan Tumpang Tindih, Hambatan Terbesar Penegakan Hukum Laut. Beritasatu. 